\title{
3.7. THE LINK BETWEEN COMMUNITY SITES AND ONLINE SALES
}

\begin{abstract}
Summary
In today's business life we have to be continuously innovative and competitive. We have always need to carry out surveys to define our target audience to keep our products/services/brand competitive compared to our rivals. Facebook and other social networking websites are the perfect virtual scenes, where businesses can be found easily. With the Internet becoming more popular and accessible, the relationship between companies and their customers has drastically changed. The sale process is becoming a more two-way communication relationship. However, the social networking sites can not only be used by companies to sell their products, but they can be used by potential customers to buy as well. Customers can easily interact with others, share their experiences and opinions about a product or a service. Facebook plays a very important role in brand building because it can have huge effects on the image I am trying to build. After finishing my research, I believe that the increasing lack of personal face-to-face communication can be replaced either by a virtual representative or a customer service online chat function.

I divided the group of 201 social media users by age, gender and region. Then, I carried out comparative analyses using the SPSS statistical software.

The results I received during my research helped me to successfully establish the two channels - social media sites, online sales - precisely and in parallel represent the target audience. I also received answers for most of the foresaid questions, which I am going to talk more about in this publication.
\end{abstract}

Keywords: online marketing, online target group, community sites, e-commerce

\section{Introduction}

Within a few years our world has undergone a radical change in the way we view our social values and consumer society. It is difficult to predict the outcome of these changes in an accurate manner. Internet was only used as a source of data a couple of years ago. However, the Web 2.0 revolution has completely changed the nature of human communication. Also by now it is not just about collecting data form on the Internet but exchanging data between users also. Today's business life means innovation and continuous competition. Companies have to have needs-assessment and define their target all the time (in many ways) in order to keep products/services/brand competitive compared to the market. The Facebook and other social networking and media sites are the channels, where companies can easily be found. Potential costumers spends a lot of their free time surfing on these websites and because of this, there is a perfect chance for them to learn more about various organisations advertised 
Tari, K.

on these type of websites. In today's world, potential buyers spend a lot of their time online, especially on social media sites, and this is where they have the opportunity to get to know the respective companies. The advent of internet there is a brand new, changed relationships between companies and customers. The sales processes are becoming into two-way communication relationships. With the social networking sites not only the sellers, but also another potential buyer can interact, share their experiences, opinions and impressions on customers.

\section{Keep in touch!}

This short sentence serves as an ending to most of the English-speaking private and even business conversations. Today, worldwide approximately 4 billion people use the Internet for both, personal and business purposes. In Hungary, $62 \%$ of population aged between 15 and 69 can be classed as Internet users. This means that 4,6 million of people go online at least once in every month. These Internet users spend a lot of their time on Facebook, Twitter, various online forums, social media and networking platforms. According to the data published by the Social Times, the number of Hungarian Facebook users can reach 4,4 million people, which represents 14th place in Europe and 39th place worldwide.

These numbers are on the rise and this provides a greater opportunity for the players of the consumer society. It is very common between consumers to obtain information about a product or service before purchasing. It is therefore, a legitimate question whether the online advertising through social media is an investment that pays off. The use of social media became very fashionable today. Almost all companies, large and small, can be found on Facebook. The Facebook IMEDIA PR Analytics lists an average of 12,271 Hungarian business related Facebook pages. Therefore, it is very important that companies know the shopping habits and identities of individuals using their social media sites, especially Facebook. Only companies that know what the members of their various fan sites want and how to provide them with a best possible offer can be successful in the online marketing used on social media pages.

\section{Literature overview}

It would be especially important to make use of the advantage of the social media marketing that the two-way communication is possible and works on the online channels. At first it helps to understand the needs of their customers. On the second place, it should prepare for the unexpected events and new market members just as they should obtain some profitable information about what kind of product they should enter to the market with.

The point of view from the social marketing would be very important to develop at least one prepared marketing specialist who is looking into the company's affairs and who knows more about the online campaigns too. Therefore it would not be practical to give out these tasks to an external marketing company if they have small 
or medium-sized companies (SMEs) on the online market (by personal interview with an online specialist).

Whether these companies are using well, or can they make use of opportunities offered by the social media platforms?

Ferenc Pécsi is a Hungarian online communication expert who says that only few companies can benefit from the opportunities of these social networking sites. Most of the companies are using these sites only like an extension of their marketing communication channel or for sharing their corporate information and ads on their websites. Many companies are striving to have more and more fan on the social websites, but the experts say it doesn't mean much in the terms of marketing. The companies with social networking profiles are members of the social networks who can draw the attention of their consumers on themselves and should have an advantage against the firms, who do not have any social networking site profiles, furthermore they can expand their client base and should influence the decision of customers or they can increase their sales too.

So the original purpose of marketing is therefore preserved - increase their own sales only the necessary devices are changed. To be a good business man or woman and to maintain the advantage, it is a very important basis that the company can reach their target group/market through many more channels and it will help to grow the number of their websites visitors, after then create a buyer for the company.

The first social networking sites were for the people-to-people $(\mathrm{C} 2 \mathrm{C})$ contacts, but in my opinion they are becoming shifted between business-to-people/costumer (B2C) nowadays as well.

The social networking sites can be used for the firms as a marketing tool and as a marketing method as well. As a marketing tool of your business you can create a social profile or a fan page with the basic information of your company and with this tool your visitors can get much more information about your firm if there is your own website link to seek out the company. If you are using the social media platform as marketing method than it is no more necessary to visit your own company's website. The social page gathers all the information, giving a chance to purchase or to order directly your products (vállalkozásonline.hu).

Larry Webber explained accurately why the companies should join the social media network in his book he wrote in 2009. These reasons are the following:

- customer acquisition (called landing pages);

- targeted branding;

- adopt/develop the relationships with customers, with suppliers, with manufacturers and with distributors too;

- research and development;

- amplifying the communication within the company as well.

According to the "Creative Communications Agency" you have to perform the following tasks during a social media campaign on the Facebook:

1. Develop the strategy: to define the main goals, to analyse the competitions, to integrate the social networking site to their own website, to prepare their 1-2 months schedule, to review their resources. 
Tari, K.

2. Forming a creative concept design: to develop their social media image which is created in harmony with the other creative materials of the company.

3. Development, setting: creating a community site, the subpages and the plug-in elements too (landing page, welcome - and information screen about the company, YouTube channel, RSS feeds)

4. Management of the page and the application: promotion, dissemination, expansion of their follower-camp, content-marketing, dialogue-generation, moderation, administration, monitoring, evaluation, evaluation of their strategy, modification, analysis of the monthly reports, advertise the whole campaign management.

Within the Facebook are a lot of possibilities for the businesses to promote their activities and products. One of the simplest methods is if the social media users click on the „like" button on their side. This may be achieved for example giving them a coupon or a discount after liking. With the ,like” of these users the company can reach all of the friends of the user who also receive information about the company. The companies can create events as well. If these event invitations are accepted, the news of this event can be seen on the social media news-wall so it can reach the acquaintance of the users they know. It is like a virus spreading.

I will write about the relationship between online marketing and social media. The following figure shows the proportions of taking advantage of each social networking sites in the B2C and also in the B2B sector. It is visible that the most popular social networking site is the Facebook in the case of the B2C sector, while LinkedIn by the B2B.

Table 1: Use of social media in B2B and B2C sectors

\begin{tabular}{|l|c|l|c|}
\hline \multicolumn{2}{|c|}{ B2C } & \multicolumn{2}{c|}{ B2B } \\
\hline Forums & $1 \%$ & Pinterest & $0 \%$ \\
\hline Google+ & $1 \%$ & Forums & $1 \%$ \\
\hline Pinterest & $2 \%$ & Google+ & $3 \%$ \\
\hline YouTube & $4 \%$ & YouTube & $4 \%$ \\
\hline LinkedIn & $5 \%$ & Twitter & $16 \%$ \\
\hline Twitter & $10 \%$ & Blogging & $19 \%$ \\
\hline Blogging & $11 \%$ & LinkedIn & $28 \%$ \\
\hline Facebook & $66 \%$ & Facebook & $29 \%$ \\
\hline
\end{tabular}

Source: based on Social Media Examiner 2013 research

Furthermore, the E-commerce can be classified in several ways:

- Trade between B2B companies

- B2C commerce between businesses and consumers

- B2A trade between companies and public administration

- $\mathrm{C} 2 \mathrm{C}$ consumer trade among themselves

- Relationships between public administrations and consumers C2A

- A2A between the relations of the administrations (Talyigás and Mojzes, 2004) 
The spread of the Internet has brought the possibility that the businesses are able to sell their products through this virtual tunnel. They can access more layers of the buyers, for example customers who are otherwise would not buy from them due to geographical distances but they can now present their products and their services over the Internet and the web-users can even order from them.

As it was mentioned earlier, the social networking sites can be used for the firms as a marketing tool and as a marketing method as well. The social media network sites are helpful to sell the products for example with the application called Facebook ShopTab. This allows the companies to offer the complete web shop supplies on their Facebook sides. They have to pay for this service and they are offered with three price plans. This application should be useful in addition with the existing webshop and taking advantage of the opportunities offered by social networking sites. (Blog.bluedesign.hu) The stores placed in FacebookTabs, the so-called "f-commerces" or "f-commerce" which enables that Facebook-visitors doesn't have to leave the original homepage but they can buy 'indoors'.

They offer the products within the social media network in order to make companies use the advertising via news feed as well, because it increases the number of their visitors and also their sales greatly. (marketingmorzsák, 2013)

Despite this possibility, $93.5 \%$ of the Hungarian companies who are on social media channel today, are not using the Facebook to sell, in fact, $90 \%$ of them communicate poorly, and does not taking advantage of the opportunities offered by either side.

\section{Current research}

The requiring decision problems are in a mutual relationship with the marketing plans and with the marketing information systems. In the first step I have collected the problems identified of my research - thus I examined the use of online sales and social networking sites - and then I had to sketch the decision alternatives. Than the precise hypotheses were formulated.

\section{Method}

This research was done via a quantitative method, using a questionnaire. The polling took place between $1^{\text {st }}$ August and $1^{\text {st }}$ of September 2013. The surveyed participants took part in the research through a well-known social networking site - on the Facebook - and were selected at random.

For surfing habits, social networking sites (Facebook) and shopping online testing variables based on gender (male-female) statistical analysis of parametric independent sample t-test or non-parametric tests Mann-Whitney $U$ test and cross tabulation (contingency tables) procedures used Chi 2 -tel. For some variables to examine the differences between the age groups (4 groups), ANOVA (one-way analysis of variance) or nonparametric Kruskal-Wallis $\mathrm{H}$ test was used and cross tabulation analyses Phi \& Cramer's V coefficient. The correlation between the variables for testing - Facebook usage and online shopping habits - Pearson's correlation was used. 
Tari, K.

Statistical - comparative - analyses were performed using SPSS 19.0 for Windows program has helped. I divided the group of 201 social media users by age, gender and region. Then, I carried out comparative analyses using the SPSS statistical software.

\section{Hypotheses}

$1^{\text {th }}$ hypothesis $(\mathrm{H} 1)$ is that with the popularity of social networking sites is increasing, the proportion of online sales are increased too

$2^{\text {nd }}$ hypothesis (H2) is that men became more open to the possibilities offered by online shopping earlier than women

$3^{\text {rd }}$ hypothesis $(\mathrm{H} 3)$ ) is that higher educated people with a bigger prestige, are buying more through the Internet. My last two hypothesis are looking at possible ways to advertise through social media and networking sites.

$4^{\text {th }}$ hypothesis (H4) it is worth to advertise through Facebook, as this ways companies can attract costumer attention towards their products or services.

After stating the hypotheses, I recorded the boundaries of research and the available research information. Research of the available information focused on already existing published researches and those available online. My next step was the detailed planning of the research.

\section{Design and procedure}

A research project is made up of more step constitutes each other roots, each of which are non-hierarchical, but also functionally related, such as consumer queries we continued our work. The questionnaire contained 19 questions, which can be divided into four parts.

Part 1: Internet usage patterns (questions 1-4)

Part 2: the relationship between social media and networking sites and online shopping (questions 5-6)

Part 3: online shopping habits (frequency, location and popularity. 7-17 issue) and

Part 4: vision (18-19 issue)

\section{Results}

$1^{\text {st }}$ hypothesis (H1) is that with the popularity of social networking sites increasing, the proportion of online sales too

The hypothesis is only partially confirmed because neither subjects of in-depth interviews nor survey respondents have gave clear answers. In my opinion social media advertising is rather for awareness-raising than increasing sales effectiveness.

The result of this question is precisely 3,41 , which means an intermediate result on the basis of 201 case reviews. Respondents have quoted the difficulty of measurement at 
question no. 9 because it's nearly impossible to measure it about many components that effects on it.

In case of banners click rate is about 1-2 \% at normal websites. Social media platforms have a great ability to put advertisements especially for target audiences. This makes declaring find their ways to target groups and this affects higher click rates as well.

$2^{\text {nd }}$ hypothesis (H2) is that men became more open to the possibilities offered by online shopping earlier than women

The hypothesis is true because question no. 9 had a significant result on the basis of gender. The question: „When did you buy the first time via Internet?” has resulted that men used to buy on the Internet for a long while significantly, which means about 1 year on the average.

$3^{\text {rd }}$ hypothesis (H3) ) is that higher educated people with a bigger prestige, are buying more through the Internet. My last two hypothesis are looking at possible ways to advertise through social media and networking sites.

It has resulted a partly verification because there's no relevant differences in online shopping statistically, but there're tendencies showing people with MA (or more than MA) qualification buy via Internet more often (quarter terminally). People with BA or secondary school / technical college usually buy less frequently (semi-annually).

$4^{\text {th }}$ hypothesis (H4) it is worth to advertise through Facebook, as this ways companies can attract costumer attention towards their products or services.

It's true on the basis of answers for question no. 5 which has resulted people find well positioned and nicely targeted (so which is able to reach the potential target audience) social media marketing quite effective. However it's important to note that there's no place for every brand on social networking sites.

\section{Conclusions}

The primary conclusion of the research is that users do not even prefer advertisements used on social media pages and the major drawback in online sales is the lack of personality. The secondary conclusion is that in online community personalities cannot be separated sharply for private and business-like. Therefore, the conclusion of the in-depth interviews is honest, open space of Internet, avoidance of subservience/superordinate and angles of humanity are the most important is social media advertising.

In summary, it is concluded, that companies that do not use Internet for marketing purposes, have a disadvantage compared to other companies that have a bigger online presence. 
Tari, K.

\section{References}

1. Baumann, M.-Kristner, A. C. e-Business (2000): Erfolgreich mit den neuen Medien, Böblingen, pp. 76-187.

2. Bányai, E.-Novák, P. (2011): Online üzlet marketing, Budapest, pp. 54-181.

3. Ries, U.- Mörgenthaler, T. (2011): Das inofficielle facebook-Buch, München, pp. 8-48.

4. Szabó, F. (2008): Hol a pénz az interneten, Budapest, pp. 30-104.

5. Weber, L. (2009): Marketing to the Social Web: How Digital Customer Communities Build Your Business, Hoboken, New Jersey, pp. 10-260.

6. Weber, L. (2011): Comprehensive Digital Business Strategy for the Social Media Era, Hoboken, New Jersey, pp. 34-67.

7. Cohen: B2C versus B2B, source: http://seorushnow.com/b2c-versus-b2b-the-mostimportant-social-media-platform-research/, read: 13. 06. 2013.

8. http://www.blog.bluedesign.hu/napi-rutin/e-kereskedelmi-megoldas-a-facebookon, read: 05. 06. 2013.

9. http://hvg.hu/tudomany/20110613 facebook marketing, read: 12. 05. 2013.

10. http://socialtimes.hu/articles/2013-01-28/hazankban-is-a-facebook-volt-2012legnepszerubb-kozossegi-oldala, read: 05. 06. 2013.

11. http://vállalkozásonline.hu, read: 10. 06. 2013. 